\title{
Guidelines on Vaccinations in Paediatric Haematology and Oncology Patients
}

\author{
Simone Cesaro, ${ }^{1}$ Mareva Giacchino, ${ }^{2}$ Francesca Fioredda, ${ }^{3}$ Angelica Barone, ${ }^{4}$ \\ Laura Battisti, ${ }^{5}$ Stefania Bezzio, ${ }^{2}$ Stefano Frenos, ${ }^{6}$ Raffaella De Santis, ${ }^{7}$ Susanna Livadiotti, ${ }^{8}$ \\ Serena Marinello, ${ }^{9}$ Andrea Giulio Zanazzo, ${ }^{10}$ and Désirée Caselli ${ }^{6,11}$ \\ ${ }^{1}$ Paediatric Hematology Oncology, Azienda Ospedaliera Universitaria Integrata Ospedale Borgo Roma, \\ P.le L.A. Scuro 10, 37134 Verona, Italy \\ ${ }^{2}$ Paediatric Hematology Oncology, Regina Margherita Hospital, P.zza Polonia 94, 10126 Torino, Italy \\ ${ }^{3}$ Paediatric Hematology, G. Gaslini Institute, Via Gerolamo Gaslini 5, 16148 Genova, Italy \\ ${ }^{4}$ Paediatric Hematology Oncology, Azienda Ospedaliera, Via Gramsci 14, 43100 Parma, Italy \\ ${ }^{5}$ Paediatrics, Azienda Ospedaliera, Via Lorenz Böhler 5, 39100 Bolzano, Italy \\ ${ }^{6}$ Paediatric Hematology Oncology, Azienda Ospedaliera Universitaria Meyer, Viale Pieraccini 24, 50139 Firenze, Italy \\ ${ }^{7}$ Paediatric Hematology Oncology, Casa Sollievo della Sofferenza Hospital, Viale Cappuccini 2, 71013 San Giovanni Rotondo, Italy \\ ${ }^{8}$ Paediatric Immunology and Infectious Diseases, Ospedale Bambin Gesù, Piazza di Sant'Onofrio, 4, 00165 Roma, Italy \\ ${ }^{9}$ Infectious Diseases, Azienda Ospedaliera, Via Giustiniani, 35128 Padova, Italy \\ ${ }^{10}$ Paediatric Hematology Oncology, Burlo Garofalo Institute, Via dell'Istria 65, 34137 Trieste, Italy \\ ${ }^{11}$ Medical Direction, A.O.U. Meyer, Children Hospital, Viale Pieraccini, 24, 50139 Firenze, Italy \\ Correspondence should be addressed to Désirée Caselli; d.caselli@meyer.it
}

Received 10 February 2014; Accepted 7 April 2014; Published 29 April 2014

Academic Editor: Martin Bornhaeuser

Copyright (C) 2014 Simone Cesaro et al. This is an open access article distributed under the Creative Commons Attribution License, which permits unrestricted use, distribution, and reproduction in any medium, provided the original work is properly cited.

Objective. Vaccinations are the most important tool to prevent infectious diseases. Chemotherapy-induced immune depression may impact the efficacy of vaccinations in children. Patients and Methods. A panel of experts of the supportive care working group of the Italian Association Paediatric Haematology Oncology (AIEOP) addressed this issue by guidelines on vaccinations in paediatric cancer patients. The literature published between 1980 and 2013 was reviewed. Results and Conclusion. During intensive chemotherapy, vaccination turned out to be effective for hepatitis A and B, whilst vaccinations with toxoid, protein subunits, or bacterial antigens should be postponed to the less intensive phases, to achieve an adequate immune response. Apart from varicella, the administration of live-attenuated-virus vaccines is not recommended during this phase. Family members should remain on recommended vaccination schedules, including toxoid, inactivated vaccine (also poliomyelitis), and live-attenuated vaccines (varicella, measles, mumps, and rubella). By the time of completion of chemotherapy, insufficient serum antibody levels for vaccinepreventable diseases have been reported, while immunological memory appears to be preserved. Once immunological recovery is completed, usually after 6 months, response to booster or vaccination is generally good and allows patients to be protected and also to contribute to herd immunity.

\section{Introduction}

In the last century, paediatric morbidity and mortality due to common infectious diseases were impressively reduced in developed countries through the introduction of vaccination practices [1-3]. Nowadays, vaccination programs represent a universally recognized tool to prevent the spread of many infectious agents and to reduce death and disability worldwide. For some vaccine-preventable diseases, definitive eradication has thus been achieved, such as smallpox worldwide and poliomyelitis throughout the USA and Europe [3,4]. Vaccination plans have been continuously updated during 
the last two decades due to either availability of new vaccines, such as for herpes varicella-zoster virus (VZV), pneumococcus and meningococcus $\mathrm{C}$, and human papilloma virus (HPV), or the identification of new groups and age ranges in whom the use of vaccination results in an improvement of health [5].

Paediatric malignant diseases today represent the second major cause of death in developed countries. Survival rates have improved over the last 3 decades due to the use of a multidisciplinary approach based on chemotherapy, surgery, radiotherapy, and hematopoietic stem cell transplantation and to improved supportive therapies [6].

One major draw-back of chemotherapy is the immune suppression of the patient, that requires up to 6-12 months after the end of treatment to recover [7-14]. This may have a negative impact on the efficacy of vaccinations because of complete or partial loss of protective serum antibody titres, unavoidably reduced compliance to scheduled vaccination, and the coexistence of other defects of the immune system, e.g., functional asplenia [15]. Generally, the patients cured of paediatric malignancies are not considered at higher risk of serious infectious complications than the healthy population, except for those who have been splenectomised or with a persistence of a functional asplenia. Yet, limited reports are available on long-term risk of severe infection; a persistent defect of humoral response to infection by Haemophilus influenzae or to vaccination for Streptococcus pneumoniae, measles, and rubella has been reported [11, 16]. Thus, the real need for vaccinations during and after treatment for paediatric cancer remains a relevant issue. This topic was addressed in part in previous recommendations for immunecompromised host published in 1993 and 2002; yet, the resulting statements for cancer patients were different for vaccination both during and after chemotherapy [17].

The aim of this paper is to analyse and discuss among experts, following an accepted methodology, the available literature in order to propose updated guidelines for the vaccination of paediatric cancer patients. This document does not extend to patients who have undergone hematopoietic stem cell transplant because specific guidelines have already been provided by leading scientific societies [18].

\section{Methods}

This project was developed according to the methodology suggested by the infectious diseases society of America (IDSA) [19]. A panel of experts from the working group for supportive care of the Italian Association Paediatric Hematology Oncology (AIEOP) jointly defined the questions to be answered:

(a) is there sufficient evidence to support vaccination during chemotherapy? If so, who should be vaccinated?

(b) what is the evidence concerning vaccination after completion of chemotherapy, and when should vaccinations be scheduled? (c) are vaccinations indicated for parents and other family members? If so, who should be vaccinated and when?

The panel of experts was divided into subgroups to separately review the literature on different topics: diphtheria, tetanus, pertussis (F.F., M.G., A.B.), poliomyelitis, influenza, HPV (M.G., S.B., and F.F.), hepatitis B (A.B., S.C., and F.F.), hepatitis A (L.B., S.C., and M.G.), measles, rubella, varicella (S.C., S.M, and G.Z.), meningococcus, Haemophilus, and pneumococcus (S.F., S.L., R.D.S., and D.C.).

Relevant articles in English language were selected by literature search on Pub Med (http://www.ncbi.nlm.nih.gov /PubMed/) using key-words as vaccination, pediatric, and chemotherapy. The time frame of the literature search was from January 1st, 1980 to June 30th, 2013. References of papers selected by the literature search were further assessed to identify additional relevant papers. Strength of recommendation and quality of evidence were scored as reported in Table 1.

The conclusions achieved by individual groups were presented in 2 plenary discussions before final approval. In case of disagreement, the issue was settled by discussion with an external expert. The final draft was reviewed by a second external reviewer.

\section{Results and Discussion}

3.1. Vaccination of Patients during Chemotherapy. The nonlive vaccines based on toxoid, protein subunits, bacterial antigens, or immunogenic proteins obtained with recombinant technology are not contraindicated in principle during chemotherapy $[20,21]$. This category includes vaccines for tetanus, diphtheria, pertussis, poliomyelitis, hepatitis B, influenza, Haemophilus, pneumococcus, and meningococcus. Although human papilloma virus (HPV) vaccine belongs to this group, no indication can be formulated by the panel of experts at present due to insufficient knowledge [22].

The major drawback of performing these vaccinations during the chemotherapy program is the potentially suboptimal antibody response, resulting in reduced efficacy compared to a healthy child. Yet, to follow the recommended schedule of immunisation, this may be done provided the patient is in good clinical conditions and not affected, or at specific risk to be affected, by infection or significant organ toxicity for at least 3 weeks after vaccination.

For poliomyelitis, tetanus, diphtheria, and pertussis, limited data are available on vaccination during chemotherapy; [23-26] thus, the level of evidence was scored as optional (C, III). These vaccinations are compulsory or highlyrecommended worldwide and most patients are expected to have completed ( 3 doses) or almost completed ( 2 doses) the primary vaccination schedule before paediatric malignancy is diagnosed. The need for maintaining during chemotherapy a protective level of serum antibodies for poliomyelitis and diphtheria is in part attenuated by the protection afforded by herd immunity, given the high percentage of protective antibody titres present in the healthy population.

For tetanus, policies for the management of the at-risk wound, such as washing of the wound, the use of antibiotics, 
TABLE 1: Scoring system used for the recommendations.

Strength of recommendation

A: strong evidence for efficacy and substantial clinical benefit; strongly recommended

B: strong or moderate evidence for efficacy, but only limited clinical benefit; generally recommended

C: insufficient evidence for efficacy or efficacy does not outweigh possible adverse consequences; optional

D: Moderate evidence against efficacy or for adverse outcome; generally not recommended

E: strong evidence against efficacy or for adverse outcome; never recommended
Quality of evidence

I: evidence from at least one well-executed randomized, controlled trial

II: evidence from at least one well-designed clinical trial without randomization; cohort or case-controlled analytic studies (preferable more than one centre), from multiple time-series studies; dramatic results of uncontrolled experiments

III: evidence from opinions of respected authorities based on clinical experience, descriptive studies, or reports of expert committees and passive immunoprophylaxis, are effective preventive measures that reduce the need for active immunization while the patient is on chemotherapy.

For pertussis, active immunization has been shown to be feasible in HIV patients, although the response was lower than in children not immune-compromised; no reports are available for paediatric cancer patients [25].

Several authors have assessed the efficacy of vaccination for hepatitis B virus (HBV) and hepatitis A virus (HAV) early after the diagnosis of paediatric malignancy [27-35]. This measure is generally adopted in countries with high prevalence of HBV or HAV infection, in which vaccination is not compulsory due to limited health resources. These studies showed that vaccination of seronegative patients for $\mathrm{HBV}$ and HAV in the early phase of chemotherapy reduces the risk of contracting hepatitis and confers protection to immune-compromised patients, although at a lower rate than in healthy populations or in patients off-therapy. The level of evidence was scored as moderately recommended for HBV (B, II). For HAV vaccination, the level of evidence was scored as optional (C, III) since passive immune-prophylaxis is equally effective in preventing acute hepatitis. However, the vaccination for HAV is recommended in seronegative patients with preexisting cirrhosis or other hepatic diseases or in patients living in or travelling to highly endemic countries for HAV.

Influenza is one of the community-acquired respiratory infections that can cause a significant morbidity in paediatric oncology patients, due to frequent complication by bacteremia [36] requiring hospitalization, which can be prevented. by vaccine. Several authors have shown that vaccination for influenza may generate immune responses also in children receiving chemotherapy, although at lower rates than in healthy children or children off-chemotherapy. Most of the studies included patients during the less-intensive phases of treatment, such as the maintenance phase for acute lymphoblastic leukemia [37-53]. A fourfold rise of the protective antibody serum level was found in $25 \%$ to $52 \%$ of patients [45]. Despite that, data on the impact of vaccination on the clinical outcome and seasonal morbidity for these patients are still lacking [50]. In patients receiving current chemotherapy for high-risk leukaemia, a profound reduction of B-cell lymphocyte number and function has been reported, potentially affecting immune response to influenza vaccination during the maintenance phase [51]. Overall, the level of evidence for influenza was moderately recommended (B, II).

Live attenuated influenza vaccine is not indicated in the immune-compromised host and only the inactivated preparation is allowed [54].

Invasive infections by capsulated bacteria may represent severe complications during chemotherapy, especially in leukaemic patients in whom an impairment of pneumococcal immunity has been reported $[15,16]$. There is limited experience on the use of vaccinations for Pneumococcus, Haemophilus, and Meningococcus [55-61]; in one case, a failure is reported [62]. Effective prevention remains based on prompt antibiotic treatment of febrile at-risk patients and isolation measures to prevent contact especially during periods of severe neutropenia. The level of evidence was scored as optional (C, III).

The use of attenuated-virus vaccination for measlesmumps-rubella is usually not indicated for patients on chemotherapy because they are at higher risk of fever or vaccine disease by vaccine strain [63]. In a very small cohort of patients with leukaemia vaccinated for measles (8 patients) and mumps (4 patients), transient withdrawal of chemotherapy was associated with a better seroconversion rate and tolerability. Yet, no significant conclusions can be drawn for current practice [64]. Thus, the use of these vaccinations was scored as D, III. In case of measles epidemic, considering the high morbidity and the potential for mortality in immunecompromised patients, the panel of experts suggests that the risk/benefit ratio of vaccination is individually assessed for each patient; as in HIV patients, evidence of an adequate CD4+ count may assist in the decision [64]. In this context, vaccination for measles has been scored as optional (C, III).

Luthy et al. reviewed 7 studies performed over the last 3 decades to evaluate the safety and efficacy of liveattenuated VZV vaccine administered to children with acute 
lymphoblastic leukaemia during maintenance therapy [63]. Overall, vaccination for VZV resulted in effective seroprotection with no impact on the risk of leukaemia relapse compared to unimmunized controls [65]. The rate of failure to protect from varicella was $10-13 \%$ and the development of herpes zoster was $1-3 \%$. The major drawback of this choice is the need for withdrawal of chemotherapy for 2 weeks, the occurrence of a vaccine disease in up to $20 \%-50 \%$ of the patients with the consequent need for their isolation, and the potential risk of developing a varicella-like illness [64, 66-73]. A lymphocyte count $>0.7-1.0 \times 10^{9} / \mathrm{L}$ and a platelet count $>100 \times 10^{9} / \mathrm{L}$ in patients in remission for at least 12 months are considered safe and effective to vaccinate leukemic patients for VZV [72, 73]. Vaccination is not recommended during profound leukopenia (neutrophils $<0.5 \times 10^{9} / \mathrm{L}$, lymphocytes $<0.7 \times 10^{9} / \mathrm{L}$ ) or during full-dose steroid therapy ( $>7$ days with $\geq 2 \mathrm{mg} / \mathrm{kg} /$ day of prednisone or $\geq 0.4 \mathrm{mg} / \mathrm{kg} /$ day of dexamethasone) alone or combined with other immunosuppressive drugs. VZV vaccination during induction chemotherapy for acute leukaemia remains associated with the risk to cause fatal, disseminated disease by the live-attenuated strain due to the heavy immunosuppression of the patients $[74,75]$.

The risk of mortality of varicella significantly decreased over the last 20 years with the introduction of acyclovir and, more recently, of other effective agents such as foscarnet and cidofovir [76, 77]. Taken altogether, the potential side effects must be weighed against the real benefits in any decision to vaccinate for $\mathrm{HVZ}$ seronegative leukemic patients while they are on therapy [76-78]. Given the lower risk of mortality for patients on maintenance therapy for acute lymphoblastic leukaemia (ALL), and the availability of effective antiviral drugs, the expert panel suggests that postponing vaccination for VZV until after completion of chemotherapy is an equally safe option. For these reasons, the recommendations of the experts for VZV vaccination was C, II.

Table 2 summarizes the levels of evidence for each vaccination of patients during chemotherapy.

In summary, vaccination of patients during chemotherapy, except for HBV and HAV, is recommended only during the phase of lower intensity of treatment, as indicated by a lymphocyte count $>1.0 \times 10^{9} / \mathrm{L}$, thus allowing the patient to mount an adequate immune response and/or to reduce the risks of side effects. Vaccinations that have the most benefit for patients are those for HBV and Influenza. Apart from VZV during maintenance for ALL patients, the administration of live-attenuated-virus vaccines is not indicated during chemotherapy.

3.2. Vaccination for the Family Members of Patients on Chemotherapy. During chemotherapy, vaccinations are not contraindicated in the patient's family members. The advice is to adhere to the schedule recommended by health plan or, if seronegative, to be vaccinated both for inactivated and live-attenuated vaccines (varicella, measles, mumps, and rubella). Also in the family members the inactivated poliovirus vaccine is recommended instead of oral polio [77].
Given that influenza is a highly seasonal contagious disease with higher morbidity and severe complications in cancer patients [36], it is recommended to vaccinate for influenza all family members during the fall season before the start of the epidemic period $[79,80]$. This measure contributes significantly to protecting the patient and reducing the risk of influenza. Considering the risk of VZV for an immunecompromised patient, vaccination for VZV is recommended for any family member who has no history of previous varicella (or is seronegative) [81]. The risk of transmission of virus strain vaccine by vaccinated family members is documented only in case of occurrence of postvaccination rash [77]. In this case, the temporary removal of this family member is recommended.

3.3. Vaccination after the End of Chemotherapy. Most authors found that chemotherapy is associated with the disappearance of vaccination immunity in patients who had completed the vaccination schedule before starting chemotherapy [8293]. The incidence of lack of protective antibody titres measured 6-12 months after chemotherapy varied according the type of vaccine: it was higher for HBV (about $50 \%$ of patients) whilst it was lower for measles, mumps, rubella (between $20 \%$ and $40 \%$ ), and polio-diphtheria-tetanus (between $10 \%$ and $30 \%)[12,25,65,76,82-86]$. Although there is no clear correlation between the wide variation in the preservation of vaccine immunity and the type of cancer, i.e., lymphoid versus myeloid versus solid tumour, the intensity of chemotherapy regimen has been advocated by Ek et al. to explain the insufficient immune response to tetanus, diphtheria, and Haemophilus influenzae $b$ vaccination after chemotherapy for high-risk acute lymphoblastic leukaemia, because of a delayed immune recovery and a low number of memory B cells $[14,94]$. A recent study of immune reconstitution showed that the recovery of newly developed transitional B cells and naïve B and T cells occurs rapidly, within months, whereas the recovery of memory $B$ and $T$ cells is slower and can be incomplete up to 5 years. In contrast, plasmablast $B$ cells were not affected by chemotherapy and were higher than normal in the first months of follow-up. Moreover, immunoglobulin levels normalized within weeks from the end of chemotherapy and, importantly, functional $T$ responses to antigens such as Cytomegalovirus, Herpes simplex 1, VZV, Candida, Tetanus, and Diphtheria were normal either within or after one year from the end of chemotherapy. These findings would explain the reported good responses to booster administration despite a long-lasting deficit of $\mathrm{B}$ and T memory cells [85].

Most authors agree that the interval time of 6-12 months is adequate to achieve a sufficient immune recovery that, in turn, has a key role in determining the response to vaccination $[14,20,83,85-88,91,95,96]$, but some studies have shown good results after reimmunization with inactivated vaccines already at 3 months [87].

The score assigned to revaccination or booster administration for poliomyelitis, tetanus, diphtheria, pertussis, HBV, measles, mumps, rubella, meningococcus, Haemophilus influenza, pneumococcus, influenza, and VZV is B, II. Table 2 
TABLE 2: Summary of level of evidence and recommendations for paediatric patients during and after chemotherapy.

\begin{tabular}{|c|c|c|c|c|}
\hline \multirow{2}{*}{ Vaccine } & \multicolumn{2}{|r|}{ During chemotherapy } & \multicolumn{2}{|r|}{ After chemotherapy } \\
\hline & $\begin{array}{c}\text { Level of evidence, } \\
\text { Reference }\end{array}$ & Concise recommendation & $\begin{array}{l}\text { Level of evidence } \\
\text { and reference }\end{array}$ & Concise recommendation \\
\hline Poliomyelitis & $\begin{array}{l}\text { C III } \\
{[21,23]}\end{array}$ & $\begin{array}{l}\text { Benefit of herd immunity } \\
\text { Postpone if lymphocyte count }<1.0 \times \\
10^{9} / \mathrm{L}^{* *}\end{array}$ & $\begin{array}{c}\text { B II, } \\
{[10,11,57,85,87-} \\
89,91]\end{array}$ & $\begin{array}{l}\text { Booster or vaccination } 6 \text { months after } \\
\text { stopping chemotherapy }\end{array}$ \\
\hline Diphteria & $\begin{array}{l}\text { C III } \\
{[21,24]}\end{array}$ & $\begin{array}{l}\text { As above, passive immunoprophylaxis } \\
\text { and antibiotic prophylaxis in case of } \\
\text { epidemic }\end{array}$ & $\begin{array}{c}\text { B II } \\
{[10,11,14,26,61} \\
86-91]\end{array}$ & $\begin{array}{l}\text { Booster or vaccination } 6 \text { months after } \\
\text { stopping chemotherapy } \\
\text { (adult type vaccine for age }>6 \text { years) }\end{array}$ \\
\hline Tetanus & $\begin{array}{l}\text { C III } \\
{[21,24]}\end{array}$ & $\begin{array}{l}\text { Postpone if lymphocyte count }<1.0 \times \\
10^{9} / \mathrm{L}^{* *} \\
\text { Passive immunoprophylaxis, thorough } \\
\text { washing and disinfection of wound, } \\
\text { and antibiotic therapy for wounds at } \\
\text { risk }\end{array}$ & $\begin{array}{c}\text { B II } \\
{[11,14,26,56,61} \\
86,87,89,91-93]\end{array}$ & $\begin{array}{l}\text { Booster or vaccination } 6 \text { months after } \\
\text { stopping chemotherapy }\end{array}$ \\
\hline
\end{tabular}

Postpone if lymphocyte count $<1.0 \times$

$\begin{array}{lcl} & \text { C III } & 10^{9} / \mathrm{L}^{* *} \\ \text { Pertussis } & \text { Passive immunoprophylaxis and }\end{array}$

$\begin{array}{ll}\text { C III } & \text { Passive immunoprophylaxis and } \\ \text { antibiotic prophylaxis in case of }\end{array}$ epidemic Vaccination of the seronegative

\begin{tabular}{|c|c|c|c|c|}
\hline Hepatitis A virus & $\begin{array}{c}\text { C III } \\
{[21,27-30]}\end{array}$ & $\begin{array}{l}\text { patients before starting chemotherapy } \\
\text { in highly endemic areas; alternatively, } \\
\text { passive immuneprophylaxis }\end{array}$ & $\begin{array}{l}\text { C III } \\
{[29]}\end{array}$ & $\begin{array}{l}\text { Booster or vaccination } 6 \text { months after } \\
\text { stopping chemotherapy }\end{array}$ \\
\hline Hepatitis B virus* & $\begin{array}{c}\text { B II } \\
{[21,28,31,32,34} \\
35]\end{array}$ & As above & B II & $\begin{array}{l}\text { Booster or vaccination } 6 \text { months after } \\
\text { stopping chemotherapy }\end{array}$ \\
\hline
\end{tabular}

\begin{tabular}{|c|c|c|c|c|}
\hline Influenza & $\begin{array}{c}\text { B II } \\
{[21,36-51,53]}\end{array}$ & $\begin{array}{l}\text { Vaccination yearly during fall; } \\
\text { postpone if lymphocyte count }<1.0 \times \\
10^{9} / \mathrm{L} ; * \\
\text { Vaccination of family members } \\
\text { Not administered to infants }<6 \text { months } \\
\text { of age }\end{array}$ & $\begin{array}{c}\text { B II } \\
{[14,46,49,51,52]}\end{array}$ & $\begin{array}{l}\text { Fall Season vaccination after } 3 \text { months } \\
\text { from stopping intensive chemotherapy } \\
\text { Not administered to infants }<6 \text { months } \\
\text { of age }\end{array}$ \\
\hline Meningococcus ${ }^{\S}$ & $\begin{array}{c}\text { C III } \\
{[21,56,57]}\end{array}$ & $\begin{array}{l}\text { Recommended vaccination prior to } \\
\text { splenectomy } \\
\text { Postpone vaccination if lymphocyte } \\
\text { count }<1.0 \times 10^{9} / \mathrm{L}^{* *} \\
\text { Not administered if age }<2 \text { years }\end{array}$ & $\begin{array}{l}\text { B II } \\
{[87]}\end{array}$ & $\begin{array}{l}\text { Not administered if age }<2 \text { years } \\
\text { Booster or vaccination } 6 \text { months after } \\
\text { stopping chemotherapy } \\
\text { Booster after } 3 \text { years if vaccinated at } \\
\text { age of } 2-6 \text { years }\end{array}$ \\
\hline $\begin{array}{l}\text { Haemophilus } \\
\text { influenzae }\end{array}$ & $\begin{array}{c}\text { C III } \\
{[21,24,58,61]}\end{array}$ & $\begin{array}{l}\text { Not administered if age }<2 \text { months } \\
\text { Recommended vaccination prior to } \\
\text { splenectomy } \\
\text { Postpone vaccination if lymphocyte } \\
\text { count }<1.0 \times 10^{9} / \mathrm{L}^{\circ}\end{array}$ & $\begin{array}{c}\text { B II } \\
{[11,14,87,89]}\end{array}$ & $\begin{array}{l}\text { Not administered if age }<2 \text { months } \\
\text { Booster or vaccination } 6 \text { months after } \\
\text { stopping chemotherapy }\end{array}$ \\
\hline Pneumococcus $s^{\S, \$ S}$ & $\begin{array}{c}\text { C II } \\
{[20,41,55-58]}\end{array}$ & $\begin{array}{l}\text { Recommended vaccination prior to } \\
\text { splenectomy } \\
\text { Postpone vaccination if lymphocyte } \\
\text { count }<1.0 \times 10^{9} / \mathrm{L}^{* *}\end{array}$ & $\begin{array}{l}\text { B II } \\
{[87]}\end{array}$ & $\begin{array}{l}\text { Booster or vaccination } 6 \text { months after } \\
\text { stopping chemotherapy }\end{array}$ \\
\hline $\begin{array}{l}\text { Measles, Mumps, } \\
\text { Rubella }\end{array}$ & $\begin{array}{c}\text { D III } \\
{[21,64]}\end{array}$ & $\begin{array}{l}\text { Not administered if age }<12 \text { months } \\
\text { Passive immunoprophylaxis in case of } \\
\text { contact } \\
\text { Vaccination of seronegative family } \\
\text { members }\end{array}$ & \multirow{2}{*}{$\begin{array}{l}\text { B II } \\
{[11,12,56,61,86} \\
87,89,92]\end{array}$} & \multirow[t]{2}{*}{$\begin{array}{l}\text { Not administered if age }<12 \text { months } \\
\text { Booster or vaccination } 6 \text { months after } \\
\text { stopping chemotherapy }\end{array}$} \\
\hline Measles & $\begin{array}{c}\text { CIII } \\
\text { (if epidemics) } \\
{[64]}\end{array}$ & $\begin{array}{l}\text { In case of epidemic, patient } \\
\text { vaccination if adequate CD } 4+\text { immune }^{\text {recovery }}{ }^{\circ}\end{array}$ & & \\
\hline
\end{tabular}

B II $96,87,90$, Booster or vaccination 6 months after

$[10,26,86,87,90$,
$92]$ $\begin{aligned} & \text { Booster or vaccination } 6 \\ & \text { stopping chemotherapy }\end{aligned}$

C III Booster or vaccination 6 months after

[29] stopping chemotherapy in highly endemic areas; alternatively, passive immuneprophylaxis

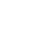


TABLE 2: Continued.

\begin{tabular}{|c|c|c|c|c|}
\hline \multirow{2}{*}{ Vaccine } & \multicolumn{2}{|r|}{ During chemotherapy } & \multicolumn{2}{|r|}{ After chemotherapy } \\
\hline & $\begin{array}{c}\text { Level of evidence, } \\
\text { Reference }\end{array}$ & Concise recommendation & $\begin{array}{l}\text { Level of evidence } \\
\text { and reference }\end{array}$ & Concise recommendation \\
\hline Varicella & $\begin{array}{c}\text { C II } \\
{[21,63,67,69-73]}\end{array}$ & $\begin{array}{l}\text { Postpone if lymphocyte count }<0.7-1.2 \\
\times 10^{9} / \mathrm{L}^{* *} \text { or the patient is not in } \\
\text { remission for } 12 \text { months or is doing } \\
\text { radiotherapy } \\
\text { Not administered if age }<12 \text { months } \\
\text { Vaccination of family members at risk; } \\
\text { Postexposure prophylaxis within } 96 \\
\text { hours from contact: hyperimmune Ig } \\
(0.2 \mathrm{~mL} / \mathrm{kg}, \text { max } 10 \mathrm{~mL}) \\
96 \text { hours after contact } \\
\text { Acyclovir } 4 \times 20 \mathrm{mg} / \mathrm{kg} / \text { day from the } \\
7 \text { th to } 21 \mathrm{st} \text { days }\end{array}$ & $\begin{array}{c}\text { B II } \\
{[11,57,65,89]}\end{array}$ & $\begin{array}{l}\text { Not administered if age }<12 \text { months } \\
\text { Booster or vaccination } 6 \text { months after } \\
\text { stopping chemotherapy }\end{array}$ \\
\hline $\begin{array}{l}\text { Human papilloma } \\
\text { virus }\end{array}$ & No data & & $\begin{array}{l}\text { C III } \\
{[22]}\end{array}$ & $\begin{array}{l}\text { Not administered if age }<9 \text { years } \\
\text { Booster or vaccination } 6 \text { months after } \\
\text { stopping chemotherapy }\end{array}$ \\
\hline Rotavirus & No data & & No data & \\
\hline \multicolumn{5}{|c|}{$\begin{array}{l}\text { Legend: } \\
{ }^{*} \text { Observe a } 4 \text {-week interval between } 1 \text { st and } 2 \text { nd doses and } 3 \text {-month interval between the } 3 \text { rd and } 4 \text { th doses of vaccine for hepatitis B virus. } \\
{ }^{\$} \text { Meningococcal and pneumococcal polysaccharide vaccines are not effective in children }<2 \text { years. } \\
{ }^{\$ S} \text { Minimum age for conjugated vaccine is } 6 \text { weeks of age. Use pneumococcal conjugate vaccine followed, after at least } 2 \text { months, by the } 23 \text { polysaccharide } \\
\text { vaccine. In case of splenectomy, give a booster after surgery. } \\
{ }^{\circ} \text { Threshold level of CD4+ recovery for MMR vaccination: CD } 4+>0.75 \times 10^{9} / \mathrm{L} \text { for children }<12 \text { months; CD } 4+>0.5 \times 10^{9} / \mathrm{L} \text { for children aged } 1-5 \text { years; }>0.2 \\
\times 10^{9} / \mathrm{L} \text { for children }>6 \text { years old and adults. } \\
\left.{ }^{* *} \text { As suggested by [ } 72,73\right] \text {. }\end{array}$} \\
\hline
\end{tabular}

summarizes the scores assigned for vaccinations after chemotherapy.

Different from other vaccinations, influenza vaccination is recommended as early as 3 months after the end of chemotherapy to confer protection while the patient is still at risk of more severe infection and complication [10, 46]. For HAV and HPV, the recommendations are based mainly on the opinion of experts because no specific data have so far been produced in these settings [22, 28] (C, III).

Considering the frequency of the loss of protective serum antibody levels after chemotherapy and the high rate of seroconversion reported with a booster or revaccination, it is not considered mandatory to measure antibody titres to decide the revaccination as well as routine checking of antibody titre response after vaccination (B, II).

In patients who stopped the course of the vaccination schedule during chemotherapy, the indication is to resume the program starting from the suspended dose (C, III).

In conclusion, chemotherapy results in a reduction of serum antibody levels for vaccine-preventable disease while immunological memory seems to be preserved. Once immunological recovery is complete, the response to vaccination is generally good, allowing patients to be protected and to contribute to herd immunity.

\section{Conflict of Interests}

No authors have conflict of interests to declare.

\section{Acknowledgments}

The authors are grateful to Giorgio Bartolozzi, M.D. Prof., and Maurizio Aricò, M.D., for their comments and critical review of the paper. The authors thank Irene Panizzolo for her skilled assistance in preparing the paper and Mr. Rodney Seddom for reviewing the English style.

\section{References}

[1] H. Peltola, "What would happen if we stopped vaccination?" The Lancet, vol. 356, no. 9248, supplement, p. s22, 2000.

[2] F. E. Andre, R. Booy, H. L. Bock et al., "Vaccination greatly reduces disease, disability, death and inequity worldwide," Bulletin of the World Health Organization, vol. 86, no. 2, pp. 140146, 2008.

[3] Centers for Disease Control and Prevention (CDC), "Recommended immunizations schedules for persons aged 0 through 18 years-United Stated 2010," Morbidity and Mortality Weekly Report, vol. 58, no. 51\&52, 2010.

[4] S. W. Roush, T. V. Murphy, M. M. Basket et al., "Historical comparisons of morbidity and mortality for vaccine-preventable diseases in the United States," Journal of the American Medical Association, vol. 298, no. 18, pp. 2155-2163, 2007.

[5] CDC, "Recommended immunization schedules for persons aged 0-18 years-United states 2010," Morbidity and Mortality Weekly Report, vol. 57, no. 51\&52, 2009. 
[6] "Principles of multimodal therapy," in Principles and Practice of Pediatric Oncology, P. A. Pizzo and D. G. Poplack, Eds., Lippincott, Philadelphia, Pa, USA, 2011.

[7] J. Katz, B. N. Walter, G. A. Bennetts, and M. S. Cairo, "Abnormal cellular and humoral immunity in childhood acute lymphoblastic leukemia in long-term remission," Western Journal of Medicine, vol. 146, no. 2, pp. 179-187, 1987.

[8] S. Alanko, T.-T. Pelliniemi, and T. T. Salmi, "Recovery of blood B-lymphocytes and serum immunoglobulins after chemotherapy for childhood acute lymphoblastic leukemia," Cancer, vol. 69, no. 6, pp. 1481-1486, 1992.

[9] J. Abrahamsson, I. Marky, and L. Mellander, "Immunoglobulin levels and lymphocyte response to mitogenic stimulation in children with malignant disease during treatment and followup," Acta Paediatrica, vol. 84, no. 2, pp. 177-182, 1995.

[10] M. M. Mustafa, G. R. Buchanan, N. J. Winick et al., "Immune recovery in children with malignancy after cessation of chemotherapy," Journal of Pediatric Hematology/Oncology, vol. 20, no. 5, pp. 451-457, 1998.

[11] S. Smith, G. Schiffman, G. Karayalcin, and V. Bonagura, "Immunodeficiency in long-term survivors of acute lymphoblastic leukemia treated with Berlin-Frankfurt-Munster therapy," Journal of Pediatrics, vol. 127, no. 1, pp. 68-75, 1995.

[12] A. Nilsson, A. De Milito, P. Engström et al., "Current chemotherapy protocols for childhood acute lymphoblastic leukemia induce loss of humoral immunity to viral vaccination antigens," Pediatrics, vol. 109, no. 6, p. e91, 2002.

[13] D. Reinhardt, K. Houliara, A. Pekrun, M. Lakomek, and B. Krone, "Impact of conventional chemotherapy on levels of antibodies against vaccine-preventable diseases in children treated for cancer," Scandinavian Journal of Infectious Diseases, vol. 35, no. 11-12, pp. 851-857, 2003.

[14] T. Ek, L. Mellander, B. Andersson, and J. Abrahamsson, "Immune reconstitution after childhood acute lymphoblastic leukemia is most severely affected in the high risk group," Pediatric Blood and Cancer, vol. 44, no. 5, pp. 461-468, 2005.

[15] R. Meisel, A. M. Toschke, C. Heiligensetzer, D. Dilloo, H.J. Laws, and R. Von Kries, "Increased risk for invasive pneumococcal diseases in children with acute lymphoblastic leukaemia," British Journal of Haematology, vol. 137, no. 5, pp. 457-460, 2007.

[16] T. Lehrnbecher, R. Schubert, M. Behl et al., "Impaired pneumococcal immunity in children after treatment for acute lymphoblastic leukaemia," British Journal of Haematology, vol. 147, no. 5, pp. 700-705, 2009.

[17] CDC, "Recommendations of the Advisory Committee of Immunization Pratices (ACIP): use of vaccines and immune globulins in persons with altered immunocompetence," Morbidity and Mortality Weekly Report, vol. 42, no. RR-4, 1993.

[18] P. Ljungman, C. Cordonnier, H. Einsele et al., "Vaccination of hematopoietic cell transplant recipients," Bone Marrow Transplantation, vol. 44, no. 8, pp. 521-557, 2009.

[19] M. A. Kish, "Guide to development of practice guidelines," Clinical Infectious Diseases, vol. 32, no. 6, pp. 851-854, 2001.

[20] D. Ridgway and L. J. Wolff, "Active immunization of children with leukemia and other malignancies," Leukemia and Lymphoma, vol. 9, no. 3, pp. 177-192, 1993.

[21] U. D. Allen, "Immunizations for children with cancer," Pediatric Blood and Cancer, vol. 49, no. 7, pp. 1102-1108, 2007.
[22] J. L. Klosky, H. L. Gamble, S. L. Spunt, M. E. Randolph, D. M. Green, and M. M. Hudson, "Human papillomavirus vaccination in survivors of childhood cancer," Cancer, vol. 115, no. 24, pp. 5627-5636, 2009.

[23] M. Stenvik, L. Hovi, M. A. Siimes, M. Roivainen, and T. Hovi, "Antipolio prophylaxis of immunocompromised children during a nationwide oral poliovaccine campaign," Pediatric Infectious Disease Journal, vol. 6, no. 12, pp. 1106-1110, 1987.

[24] D. Ridgway, L. J. Wolff, and A. Deforest, "Immunization response varies with intensity of acute lymphoblastic leukemia therapy," The American Journal of Diseases of Children, vol. 145, no. 8, pp. 887-891, 1991.

[25] M. J. Abzug, L.-Y. Song, T. Fenton et al., "Pertussis booster vaccination in HIV-infected children receiving highly active antiretroviral therapy," Pediatrics, vol. 120, no. 5, pp. el190e1202, 2007.

[26] H. J. Kwon, J.-W. Lee, N.-G. Chung, B. Cho, H.-K. Kim, and J. H. Kang, "Assessment of serologic immunity to diphtheriatetanus-pertussis after treatment of Korean pediatric hematology and oncology patients," Journal of Korean Medical Science, vol. 27, no. 1, pp. 78-83, 2012.

[27] Y. Köksal, B. Yalcin, G. B. Aydin et al., "Immunogenicity of hepatitis A vaccine in children with cancer," Pediatric HematologyOncology, vol. 23, pp. 619-624, 2006.

[28] Y. Köksal, A. Varan, G. B. Aydin et al., "Comparison of accelerated and rapid schedules for monovalent hepatitis $B$ and combined hepatitis A/B Vaccines in children with cancer," Pediatric Hematology and Oncology, vol. 24, no. 8, pp. 587-594, 2007.

[29] J. C. Victor, A. S. Monto, T. Y. Surdina et al., "Hepatitis A vaccine versus immune globulin for postexposure prophylaxis," The New England Journal of Medicine, vol. 357, no. 17, pp. 16851694, 2007.

[30] M. R. Wallace, C. J. Brandt, K. C. Earhart et al., "Safely and immunogenicity of an inactivated hepatitis A vaccine among HIV-infected subjects," Clinical Infectious Diseases, vol. 39, no. 8, pp. 1207-1213, 2004.

[31] M. Ramesh, R. K. Marwaha, Y. K. Chawla, and A. Trehan, "Seroconversion after hepatitis B vaccination in children receiving cancer chemotherapy," Indian Pediatrics, vol. 37, no. 8, pp. 882$886,2000$.

[32] S. Yetgin, B. Tunç, A. Koç, H. B. Toksoy, M. Ceyhan, and G. Kanra, "Two booster dose hepatitis B virus vaccination in patients with leukemia," Leukemia Research, vol. 25, no. 8, pp. 647-649, 2001.

[33] S. Emir, M. Büyükpamuk, C. Akyüz, T. Kutluk, E. Güler, and K. Caglar, "The comparison of antibody response to different hepatitis B vaccines with and without pre-S2 antigen in children with cancer," Pediatric Hematology-Oncology, vol. 19, pp. 227233, 2002.

[34] S. Yetgin, B. Tavil, S. Aytac, B. Kuskonmaz, and G. Karna, "Unexpected protection from infection by two booster hepatitis $B$ virus vaccination in children with acute lymphoblastic leukemia," Leukemia Research, vol. 31, no. 4, pp. 493-496, 2007.

[35] L. Hovi, M. Valle, M. A. Siimes, H. Jalanko, and U. M. Saarinen, "Impaired response to hepatitis B vaccine in children receiving anticancer chemotherapy," Pediatric Infectious Disease Journal, vol. 14, no. 11, pp. 931-935, 1995. 
[36] S. K. Tasian, J. R. Park, E. T. Martin, and J. A. Englund, "Influenza-associated morbidity in children with cancer," Pediatric Blood and Cancer, vol. 50, no. 5, pp. 983-987, 2008.

[37] B. Lange, S. A. Shapiro, and M. T. G. Waldman, "Antibody responses to influenza immunization of children with acute lymphoblastic leukemia," Journal of Infectious Diseases, vol. 140, no. 3, pp. 402-406, 1979.

[38] A. Kempe, C. B. Hall, N. E. MacDonald et al., "Influenza in children with cancer," Journal of Pediatrics, vol. 115, no. 1, pp. 33-39, 1989.

[39] P. G. Steinherz, A. E. Brown, and P. A. Gross, "Influenza immunization of children with neoplastic diseases," Cancer, vol. 45, no. 4, pp. 750-756, 1980.

[40] J. C. Chisholm, T. Devine, A. Charlett, C. R. Pinkerton, and M. Zambon, "Response to influenza immunisation during treatment for cancer," Archives of Disease in Childhood, vol. 84, no. 6, pp. 496-500, 2001.

[41] T. Nordøy, I. S. Aaberge, A. Husebekk et al., "Cancer patients undergoing chemotherapy show adequate serological response to vaccinations against influenza virus and Streptococcus pneumoniae," Medical Oncology, vol. 19, no. 2, pp. 71-78, 2002.

[42] Y. C. Hsieh, M. Y. Lu, C. L. Kao et al., "Response to influenza vaccine in children with leukemia undergoing chemotherapy," Journal of the Formosan Medical Association, vol. 101, pp. 700704, 2002.

[43] C. C. Porter, K. M. Edwards, Y. Zhu, and H. Frangoul, "Immune responses to influenza immunization in children receiving maintenance chemotherapy for acute lymphoblastic leukemia," Pediatric Blood and Cancer, vol. 42, no. 1, pp. 36-40, 2004.

[44] J. Chisholm, K. Howe, M. Taj, and M. Zambon, "Influenza immunisation in children with solid tumours," European Journal of Cancer, vol. 41, no. 15, pp. 2280-2287, 2005.

[45] A. Matsuzaki, A. Suminoe, Y. Koga, N. Kinukawa, K. Kusuhara, and T. Hara, "Immune response after influenza vaccination in children with cancer," Pediatric Blood and Cancer, vol. 45, no. 6, pp. 831-837, 2005.

[46] G. M. Goossen, L. C. M. Kremer, and M. D. van De Wetering, "Influenza vaccination in children being treated with chemotherapy for cancer," Cochrane Database of Systematic Reviews, no. 2, Article ID CD006484, 2007.

[47] L. S. Kersun, A. Reilly, and S. E. Coffin, "A prospective study of chemotherapy immunologic effects and predictors of humoral influenza vaccine responses in a pediatric oncology cohort," Influenza and Other Respiratory Viruses, vol. 7, no. 6, pp. 11581167, 2012.

[48] A. M. Mavinkurve-Groothuis, M. van der Flier, F. Stelma, C. van Leer-Buter, F. W. Preijers, and P. M. Hoogerbrugge, "Absolute lymphocyte count predicts the response to new influenza virus H1N1 vaccination in pediatric cancer patients," Clinical and Vaccine Immunology, vol. 20, pp. 118-121, 2013.

[49] K. Shahin, B. Lina, G. Billaud, C. Pedone, and C. FaureConter, "Successful H1N1 influenza vaccination of children receiving chemotherapy for solid tumors," Journal of Pediatric Hematology/Oncology, vol. 34, pp. e228-e231, 2012.

[50] D. Doganis, M. Tsolia, H. Dana et al., "Compliance with immunization against H1N1 influenza virus among children with cancer," Pediatric Hematology-Oncology, vol. 30, pp. 149153, 2013.
[51] T.-Y. Yen, S.-T. Jou, Y.-L. Yang et al., "Immune response to 2009 pandemic H1N1 influenza virus A monovalent vaccine in children with cancer," Pediatric Blood and Cancer, vol. 57, no. 7, pp. 1154-1158, 2011.

[52] O. Bektas, C. Karadeniz, A. Oguz, S. Berberoglu, N. Yilmaz, and C. Citak, "Assessment of the immune response to trivalent split influenza vaccine in children with solid tumors," Pediatric Blood and Cancer, vol. 49, no. 7, pp. 914-917, 2007.

[53] D. Engelhard, B. Mohty, R. de la Camara, C. Cordonnier, and P. Ljungman, "European guidelines for prevention and management of influenza in hematopoietic stem cell transplantation and leukemia patients: summary of ECIL-4 (2011), on behalf of ECIL, a joint venture of EBMT, EORTC, ICHS, and ELN," Transplant Infectious Disease, vol. 15, pp. 219-232, 2013.

[54] Centers for Diseases Control and Prevention, "Prevention and control of influenza with vaccines," Morbidity and Mortality Weekly Report, vol. 59, no. RR-8, 2010.

[55] T. E. Caver, K. S. Slobod, P. M. Flynn et al., "Profound abnormality of the B/T lymphocyte ratio during chemotherapy for pediatric acute lymphoblastic leukemia," Leukemia, vol. 12, no. 4, pp. 619-622, 1998.

[56] J. Rautonen, M. A. Siimes, and U. Lundstrom, "Vaccination of children during treatment for leukemia," Acta Paediatrica Scandinavica, vol. 75, no. 4, pp. 579-585, 1986.

[57] J. W. Yu, A. Borkowski, L. Danzig, S. Reiter, P. Kavan, and B. D. Mazer, "Immune response to conjugated meningococcal $\mathrm{C}$ vaccine in pediatric oncology patients," Pediatric Blood and Cancer, vol. 49, no. 7, pp. 918-923, 2007.

[58] S. Feldman, F. Gigliotti, J. L. Shenep, P. K. Roberson, and L. Lott, "Risk of Haemophilus influenzae type b disease in children with cancer and response of immunocompromised leukemic children to a conjugate vaccine," Journal of Infectious Diseases, vol. 161, no. 5, pp. 926-931, 1990.

[59] S. S. Donaldson, K. L. Vosti, F. R. Berberich, R. S. Cox, H. S. Kaplan, and G. Schiffman, "Response to pneumococcal vaccine among children with Hodgkin's disease," Reviews of Infectious Diseases, vol. 3, pp. S133-S143, 1981.

[60] S. Feldman, W. Malone, R. Wilbur, and G. Schiffman, "Pneumococcal vaccination in children with acute lymphocytic leukemia," Medical and Pediatric Oncology, vol. 13, no. 2, pp. 6972, 1985.

[61] E. Zengin and N. Sarper, "Humoral immunity to diphtheria, tetanus, measles, and hemophilus influenzae type b in children with acute lymphoblastic leukemia and response to revaccination," Pediatric Blood and Cancer, vol. 53, no. 6, pp. 967972, 2009.

[62] J. Nevin, J. Kanter Washko, and J. Arnold, "Haemophilus influenzae type B in an immunocompetent, fully vaccinated ALL survivor," Pediatrics, vol. 131, pp. e1639-e1642, 2013.

[63] K. E. Luthy, M. E. Tiedemann, R. L. Beckstrand, and D. A. Mills, "Safety of live-virus vaccine for children with immunodeficiency," Journal of the American Academy of Nurse Practitioners, vol. 18, pp. 494-503, 2006.

[64] S. Torigoe, S. Hirai, K. Oitani et al., "Application of live attenuated measles and mumps vaccines in children with acute leukemia," Biken Journal, vol. 24, no. 4, pp. 147-151, 1981.

[65] F. B. Cakir, C. Timur, A. Yoruk, E. Cakir, and A. C. Ayhan, "Seroconversion status after single dose and double doses 
of varicella vaccination in children with leukemia," Pediatric Hematology and Oncology, vol. 29, no. 2, pp. 191-194, 2012.

[66] A. M. Geretti and T. Doyle, "Immunization for HIV-positive individuals," Current Opinion in Infectious Diseases, vol. 23, no. 1, pp. 32-38, 2010.

[67] S. H. Slørdahl, D. Wiger, T. Strømøy, M. Degre, E. Thørsby, and S. O. Lie, "Vaccination of children with malignant disease against varicella," Postgraduate Medical Journal, vol. 61, supplement 4, pp. 85-92, 1985.

[68] A. A. Gershon, S. Steinberg, L. Gelb et al., "A multicentre trial of live attenuated varicella vaccine in children with leukaemia in remission," Postgraduate Medical Journal, vol. 61, no. 4, pp. 73-78, 1985.

[69] A. A. Gershon, S. P. Steinberg, and L. Gelb, "Live attenuated varicella vaccine use in immunocompromised children and adults," Pediatrics, vol. 78, no. 4, pp. 757-762, 1986.

[70] R. J. Haas, B. Belohradsky, R. Dickerhoff et al., "Active immunization against varicella of children with acute leukaemia or other malignancies on maintenance chemotherapy," Postgraduate Medical Journal, vol. 61, supplement 4, pp. 69-72, 1985.

[71] C.-Y. Yeung and D.-C. Liang, "Varicella vaccine in children with acute lymphoblastic leukemia and non-Hodgkin lymphoma," Pediatric Hematology and Oncology, vol. 9, no. 1, pp. 29-34, 1992.

[72] T.-F. Leung, C.-K. Li, E. C. W. Hung et al., "Immunogenicity of a two-dose regime of varicella vaccine in children with cancers," European Journal of Haematology, vol. 72, no. 5, pp. 353-357, 2004.

[73] A. M. C. Sartori, "A review of the varicella vaccine in immunocompromised individuals," International Journal of Infectious Diseases, vol. 8, no. 5, pp. 259-270, 2004.

[74] A. Schrauder, C. Henke-Gendo, K. Seidemann et al., "Varicella vaccination in a child with acute lymphoblastic leukaemia," The Lancet, vol. 369, no. 9568, p. 1232, 2007.

[75] V. Grote, R. Von Kries, W. Springer, G. Hammersen, H. Wolfgang Kreth, and J. Liese, "Varicella-related deaths in children and adolescents-Germany 2003-2004," Acta Paediatrica, vol. 97, no. 2, pp. 187-192, 2008.

[76] M. A. Caniza, S. P. Hunger, A. Schrauder et al., "The controversy of varicella vaccination in children with acute lymphoblastic leukemia," Pediatric Blood and Cancer, vol. 58, no. 1, pp. 12-16, 2012.

[77] M. Kamboj and K. A. Sepkowitz, "Risk of transmission associated with live attenuated vaccines given to healthy persons caring for or residing with an immunocompromised patient," Infection Control and Hospital Epidemiology, vol. 28, no. 6, pp. 702-707, 2007.

[78] D. K. Cheuk, A. K. Chiang, T. L. Lee, G. C. Chan, and S. Y. $\mathrm{Ha}$, "Vaccines for prophylaxis of viral infections in patients with hematological malignancies," Cochrane Database of Systematic Reviews, vol. 3, Article ID CD006505, 2011.

[79] C. Casper, J. Englund, and M. Boeckh, "How I treat influenza in patients with hematologic malignancies," Blood, vol. 115, no. 7, pp. 1331-1342, 2010.

[80] Y.-C. T. Shih and I.-W. Pan, "Influenza vaccination among individuals with cancer and their family members," The American Journal of Preventive Medicine, vol. 38, no. 1, pp. 61-69, 2010.

[81] P. S. Diaz, D. Au, S. Smith et al., "Lack of transmission of the live attenuated varicella vaccine virus to immunocompromised children after immunization of their siblings," Pediatrics, vol. 87, no. 2, pp. 166-170, 1991.

[82] C. M. van Tilburg, E. A. M. Sanders, M. M. Rovers, T. F. W. Wolfs, and M. B. Bierings, "Loss of antibodies and response to (re-)vaccination in children after treatment for acute lymphocytic leukemia: a systematic review," Leukemia, vol. 20, no. 10, pp. 1717-1722, 2006.

[83] F. W. T. Cheng, F. L. Ting, P. K. S. Chan et al., "Humoral immune response after post-chemotherapy booster diphtheria-tetanuspertussis vaccine in pediatric oncology patients," Pediatric Blood and Cancer, vol. 52, no. 2, pp. 248-253, 2009.

[84] N. W. Crawford, J. A. Heath, D. Ashley, P. Downie, and J. P. Buttery, "Survivors of childhood cancer: an Australian audit of vaccination status after treatment," Pediatric Blood and Cancer, vol. 54, no. 1, pp. 128-133, 2010.

[85] M. Zignol, M. Peracchi, G. Tridello et al., "Assessment of humoral immunity to poliomyelitis, tetanus, hepatitis B, measles, rubella, and mumps in children after chemotherapy," Cancer, vol. 101, no. 3, pp. 635-641, 2004.

[86] A. Ruggiero, A. Battista, P. Coccia, G. Attinà, and R. Riccardi, "How to manage vaccinations in children with cancer," Pediatric Blood and Cancer, vol. 57, no. 7, pp. 1104-1108, 2011.

[87] S. R. Patel, M. Ortín, B. J. Cohen et al., "Revaccination of children after completion of standard chemotherapy for acute leukemia," Clinical Infectious Diseases, vol. 44, no. 5, pp. 635642, 2007.

[88] J. Yu, A. J. Chou, A. Lennox et al., "Loss of antibody titers and effectiveness of revaccination in post-chemotherapy pediatric sarcoma patients," Pediatric Blood and Cancer, vol. 49, no. 5, pp. 656-660, 2007.

[89] D. H. Brodtman, D. W. Rosenthal, A. Redner, P. Lanzkowsky, and V. R. Bonagura, "Immunodeficiency in children with acute lymphoblastic leukemia after completion of modern aggressive chemotherapeutic regimens," Journal of Pediatrics, vol. 146, no. 5, pp. 654-661, 2005.

[90] A. van Der Does-Van Den Berg, J. Hermans, J. Nagel, and G. van Steenis, "Immunity to diphtheria, pertussis, tetanus, and poliomyelitis in children with acute lymphocytic leukemia after cessation of chemotherapy," Pediatrics, vol. 67, no. 2, pp. 222$229,1981$.

[91] K. von der Hardt, J. Jüngert, J. D. Beck, and U. Heininger, "Humoral immunity against diphtheria, tetanus and poliomyelitis after antineoplastic therapy in children and adolescents-a retrospective analysis," Vaccine, vol. 18, no. 26, pp. 2999-3004, 2000.

[92] T. E. Ercan, L. Y. Soycan, H. Apak et al., "Antibody titers and immune response to diphtheria-tetanus-pertussis and measles-mumps-rubella vaccination in children treated for acute lymphoblastic leukemia," Journal of Pediatric Hematology/Oncology, vol. 27, no. 5, pp. 273-277, 2005.

[93] F. Fioredda, A. Plebani, G. Hanau et al., "Re-immunisation schedule in leukaemic children after intensive chemotherapy: a possible strategy," European Journal of Haematology, vol. 74, no. 1, pp. 20-23, 2005.

[94] T. Ek, L. Mellander, M. Hahn-Zoric, and J. Abrahamsson, "Intensive treatment for childhood acute lymphoblastic leukemia reduces immune responses to diphtheria, tetanus, and Haemophilus influenzae type b," Journal of Pediatric Hematology/Oncology, vol. 26, no. 11, pp. 727-734, 2004. 
[95] C. M. van Tilburg, R. van Gent, M. B. Bierings et al., "Immune reconstitution in children following chemotherapy for haematological malignancies: a long-term follow-up," British Journal of Haematology, vol. 152, no. 2, pp. 201-210, 2011.

[96] S. Esposito, V. Cecinati, B. Scicchitano et al., "Impact of influenza-like illness and effectiveness of influenza vaccination in oncohematological children who have completed cancer therapy," Vaccine, vol. 28, no. 6, pp. 1558-1565, 2010. 


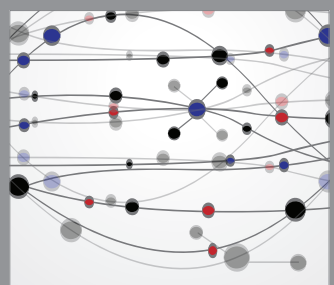

The Scientific World Journal
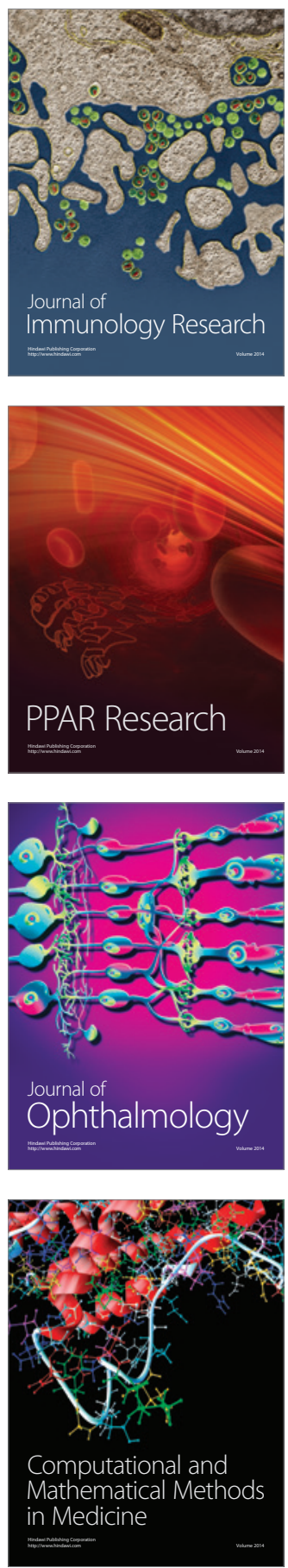

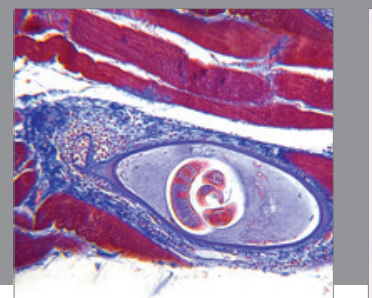

Gastroenterology

Research and Practice
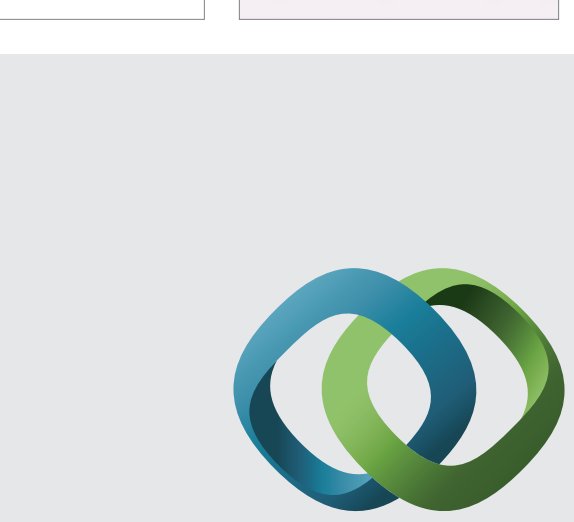

\section{Hindawi}

Submit your manuscripts at

http://www.hindawi.com
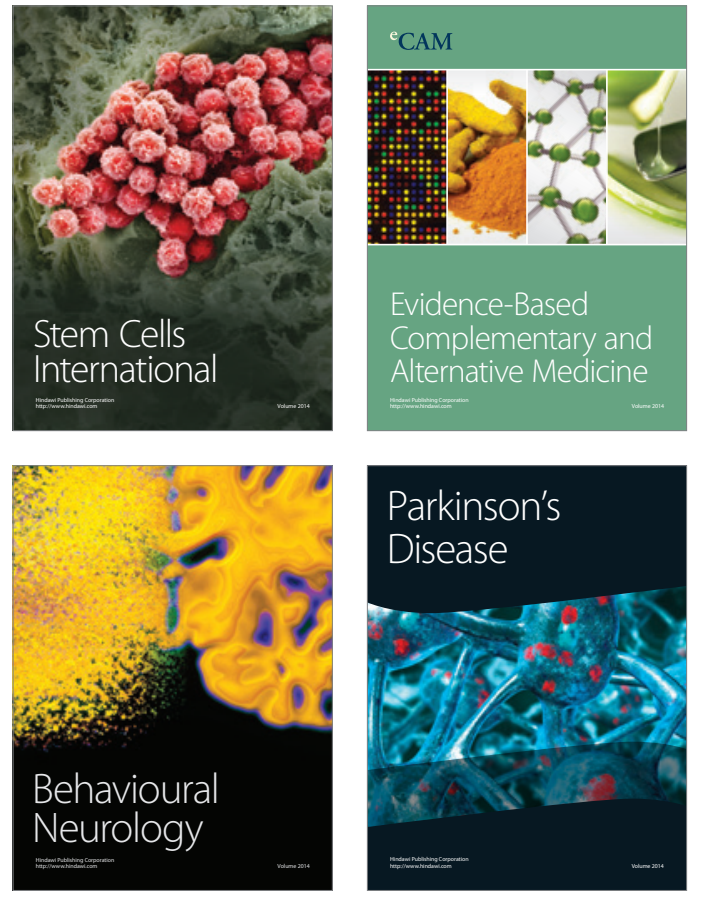
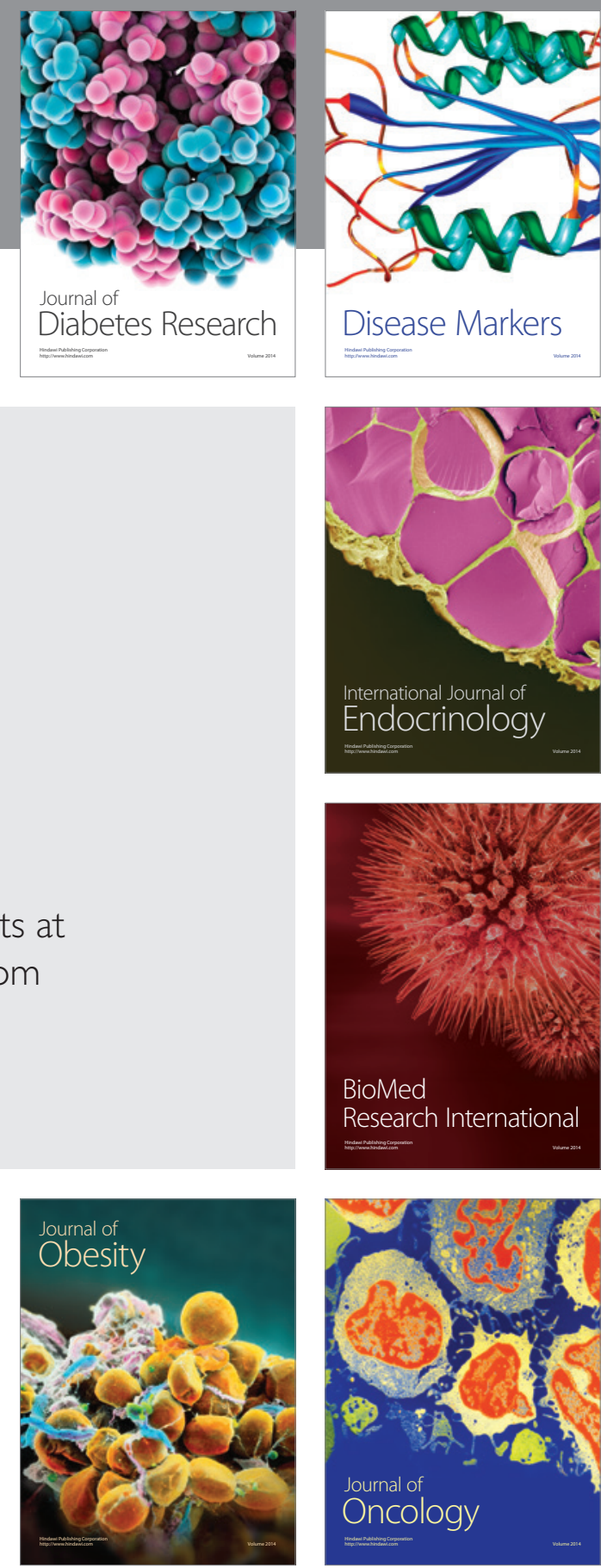

Disease Markers
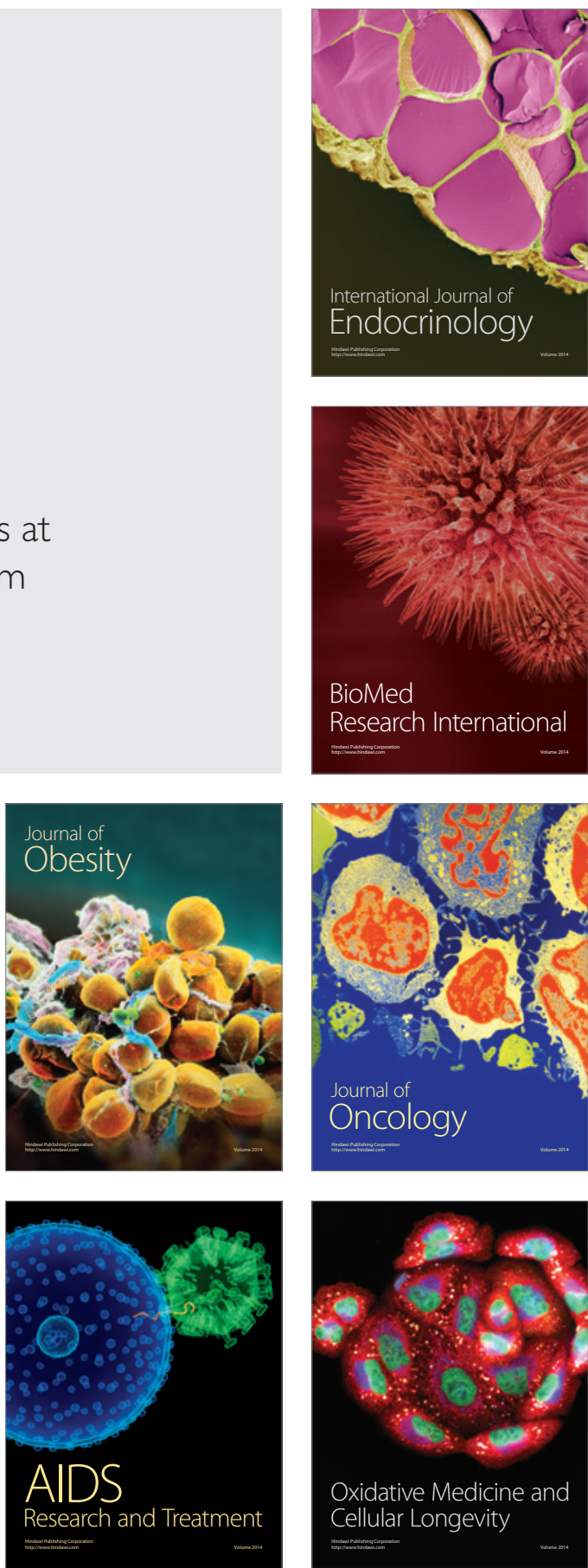